\title{
Egyptian Revival in the manor parks of Latvia
}

\author{
Jānis Zilgalvis, Dr. arch., a full member of the Latvian Academy of Sciences
}

\begin{abstract}
Eclecticism (historicism) has a wide range of formal stylistic trends and variations, such as Neo-Gothic, Neo-Renaissance, Neo-Baroque and others. They were once popular and they have left many noteworthy monuments, although the trend called Egyptian style or Egyptian Revival is less known. There are very few studies on the manifestations of this style in the parks of Latvian manors, where, though not very numerous, the pyramids, obelisks and the like can be found. It should be noted that architectural and artistic objects used to be an integral part of the parks and they largely determined the emotional mood of the parks. Today, particular attention should be paid to the preservation of these elements in the cultural and historical environment.
\end{abstract}

Keywords: architectural heritage, monument protection and preservation, historical parks and gardens

The spread of Egyptian style in Europe and its research

A number of studies have been carried out on the spread, evolution, and monuments of the so called Egyptian style in Europe reflecting the constant interest in Egyptian architecture in the 18th and 19th centuries, with both calmer moments and flourishing periods [1]. The Egyptian pyramids and the cult of the dead drew the attention of the ancient Romans, who introduced some elements and forms in their own architecture. In the18th century the exotic and picturesque motifs and formations came into fashion, the spread of which was promoted by romanticism, started already by Rococo artists. They mainly dealt with formal aesthetic and symbolic iconographic types of problems. It was important to create the mood related to a specific place - most often a garden or a park - that could be achieved with such exotically romantic structures as Chinese pagodas, Greek temples, Gothic ruins or Egyptian pyramids and obelisks.

Pyramids played a special role in the trend of Egyptian Revival in the architecture of Europe from the middle of the $18^{\text {th }}$ century till the early 19th century. They were mainly used for memorial sites - burials, chapels, temples. Pyramids were already found in the engravings of the artist Giovanni Battista Piranesi in 1748 [2]. They were also represented in the collections of architectural sketches of Jean François de Neufforge [3] and Johann Fischer von Erlach's first widely illustrated architectural history [4]. The form of the pyramid at that time and also later was supplemented in a variety of ways. Most often the details of classical architecture were added. It should also be noted that it was not necessary to accurately follow the proportions of the Egyptian pyramids. For example, in England a classical portico was added to the pyramid of the gate of the manor Nostell Priory, West Yorkshire (1776). It is noted as being one of the most outstanding works of this type created by architect Robert Adam [5]. A similar one is the Egyptian temple designed by architect John Soane in 1778 . This architectural drawing was included in the publication Designs in Architecture [6], whereas all the facets of the pyramid-temple Chapelle Sepulcrale (1748) depicted by Nicholas Henry Jardin (N. H. Jardin), are adorned with porticos [7].

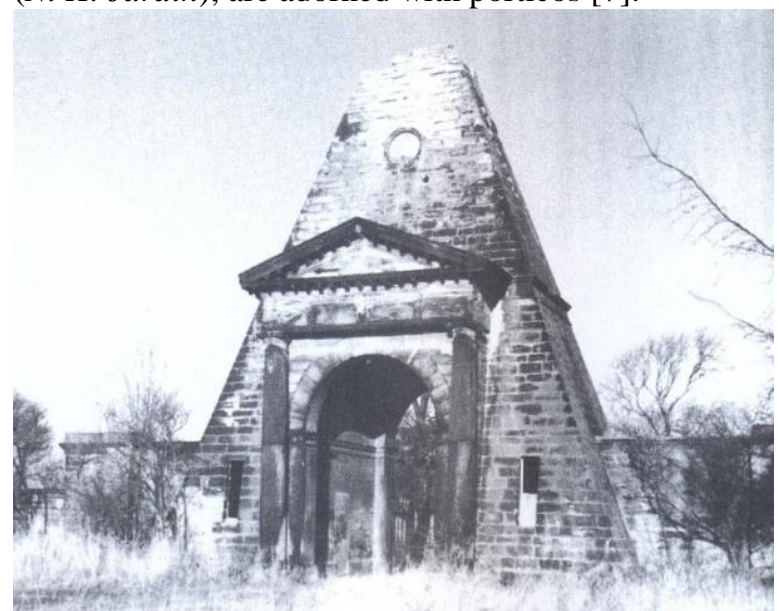

Fig. 1. Nostell Priory: Featherstone entrance, 1776 [King D. The complete works of Robert and James Adam. Oxford, 1991]

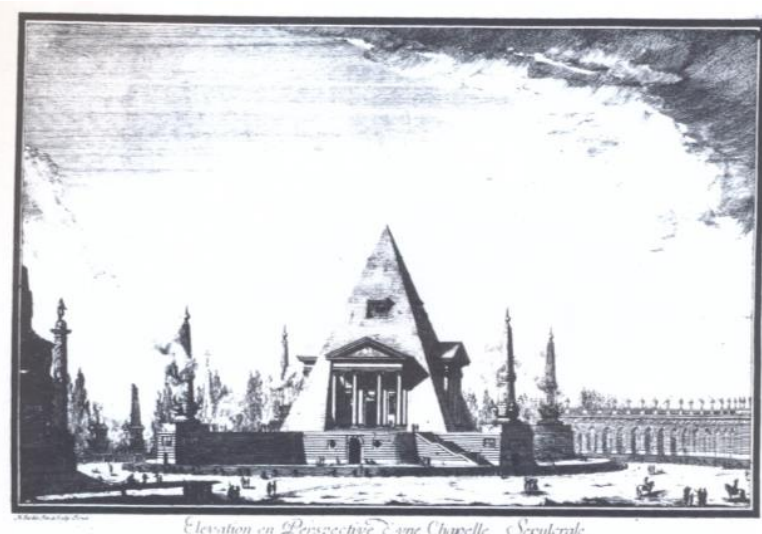

Fig. 2. Perspective of Chapelle Sepulcrale, N. H. Jardin, 1748 [Wittkower R. Essays in the History of Architecture. London, 1967] 


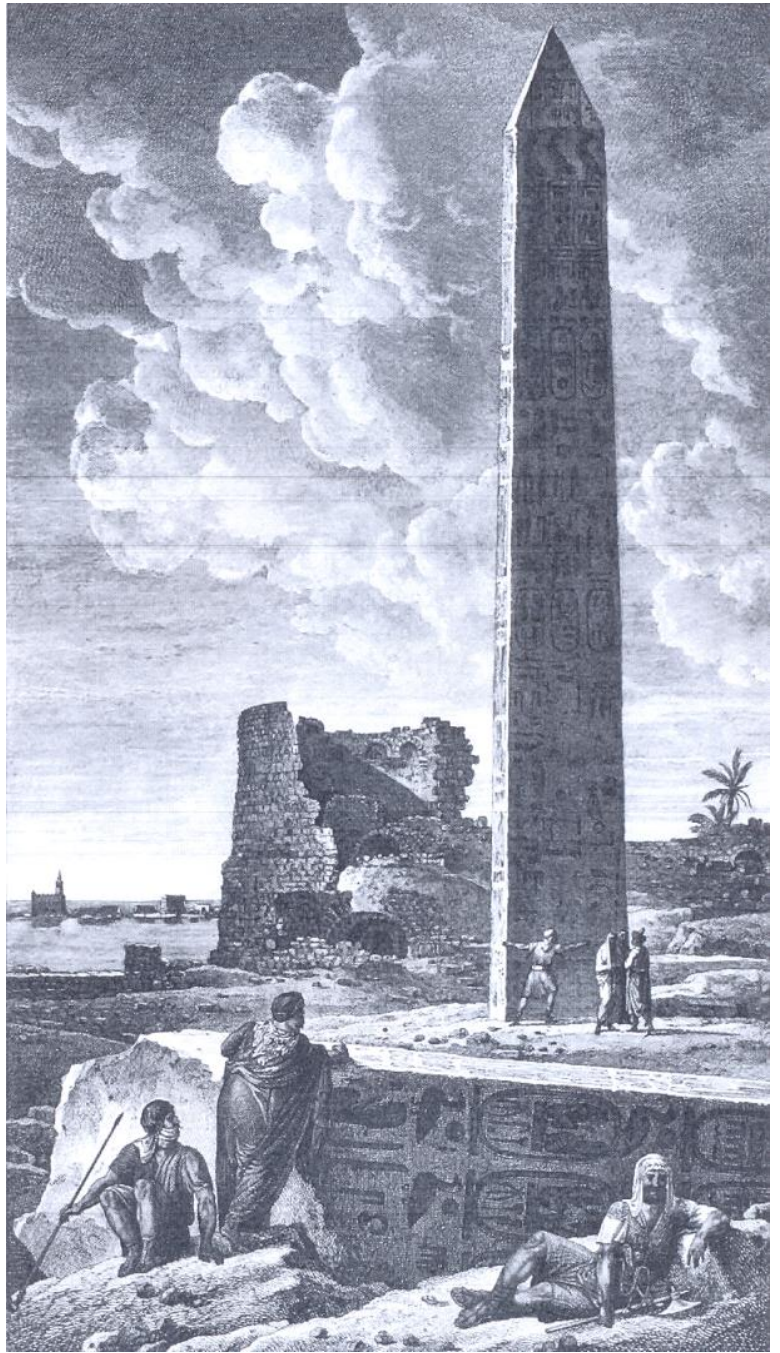

Fig. 3. L. F. Cassas's engraving of the year 1799 Alexander's tomb stone [Cleopatra's Needles and the Tower of the Romans in Alexandria (1785) by L. F. Cassas engraving

Chugg A. M The Quest for the Tomb of Alexander the Great (2nd Ed.). (s.1.): (s.n.), 2012, p. 121, Fig. 6.3. ISBN: 9780955679063]

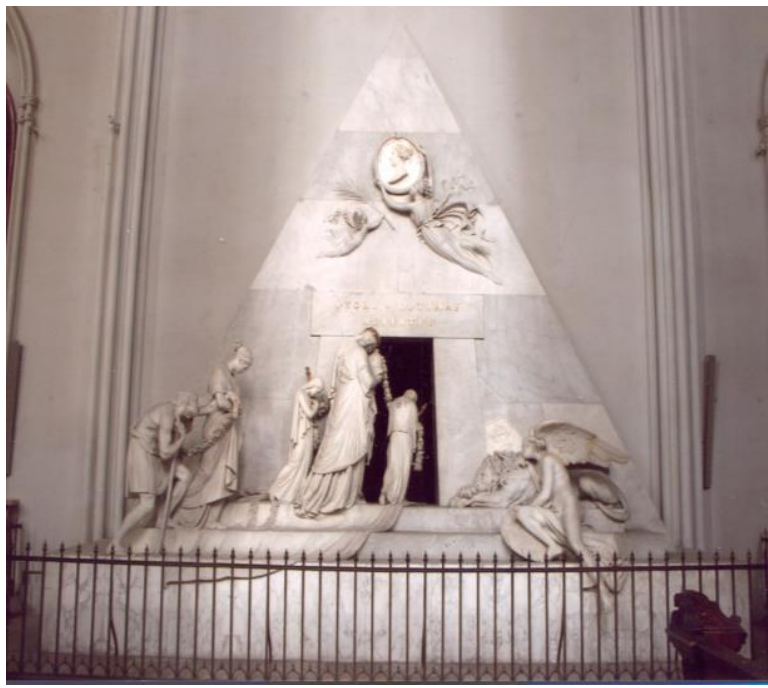

Fig. 4. Tombstone monument of Duchess Maria Christina in St. Augustine church in Vienna [photo by the author, 2010]

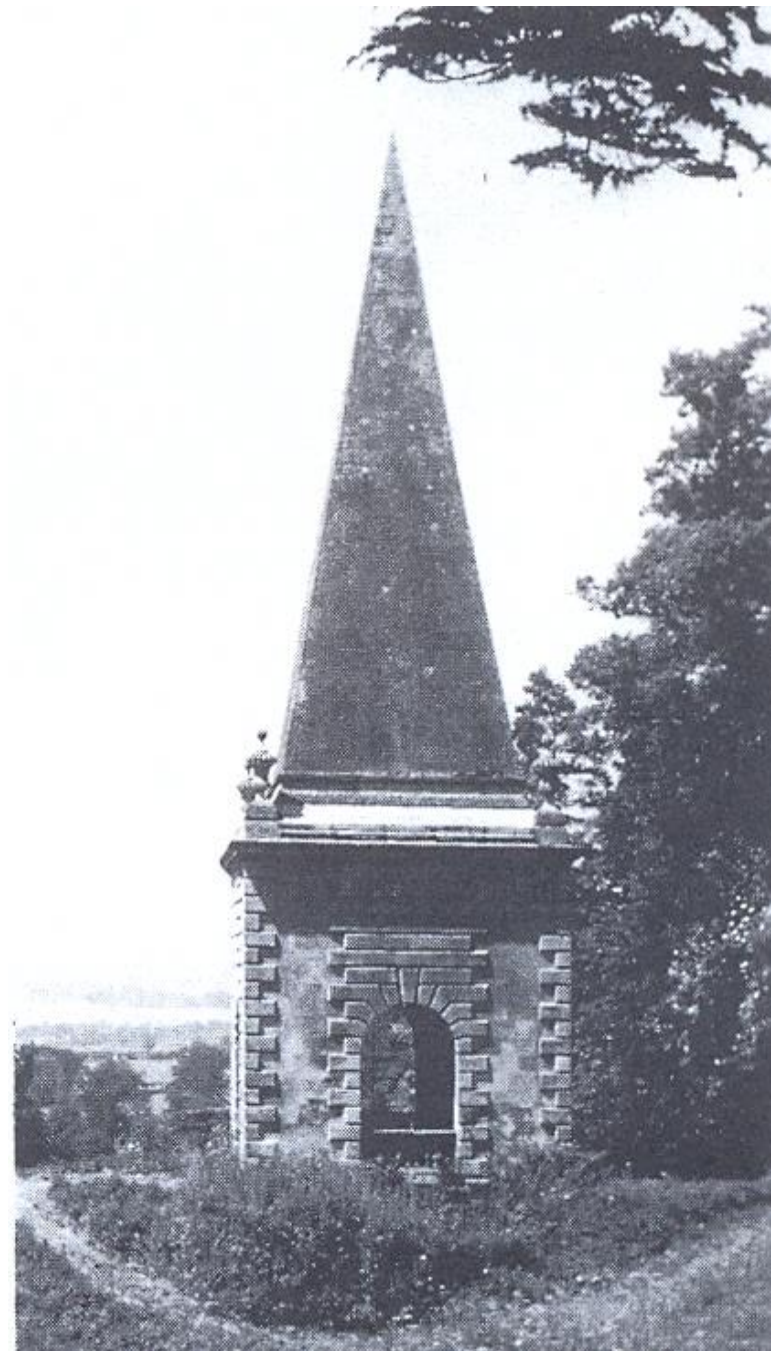

Fig. 5. The Pyramid, built by R. Tracy in memory of his father. Stanway House, Tewkesbury Abbey

[Lees - Milne J. Some Cotswold Country Houses. Stanbridge: Dovecote Press, 1987]

This example seems to have been particularly popular since it was often repeated later. For example, the temple designed by architect Friedrich Gilly in Berlin (around 1797), a monument dedicated to the Tartar defeat in Kazan, Russia (1823-1830, architect M. Alferov), and others. There are also other types of the use of pyramids. For example, the English architect John Carter, in the Builders Magazine, year 1777, recommended it for the construction of a dairy [8], but the pyramid built in Sanssouci park in Potsdam, Germany, in the 18th century served as an ice cellar. It was raised on a high socle floor, whose walls were decorated with horizontal niches which were filled with hieroglyphs. The entrance was emphasized by an ordinary portal.

Napoleon's Egyptian military campaign played a great role in the popularisation of the pyramids and Egyptian culture over the course of time. The army was followed by a whole host of monument researchers, artists and archeologists. As a result of their work, several significant publications were 
printed. One of them was the 21-volume publication Egyptian description or a collection of notes which was created in Egypt during the expedition of the French Army [9], a copy of which is also available at the Library of the University of Latvia. The revival of the Egyptian culture was also promoted by the artists of that period, for example, painter H. Robert painted pyramids as gigantic structures and people around them in microscopic sizes. In 1799, Louis-François Cassas published the engravings of temples, gates and other buildings according to the sketches of his of previous years' travels.

Regarding the pyramids, their idea has been transformed as a result of iconographic studies and this suggests that Egyptian architectural forms have been used only symbolically to create specific historical associations. An example of this is the cenotaph proposal by Jean-Nicolas-Louis Durand (1805), where the interior of the pyramid is covered with a dome [10], so an opposite construction is used for the outside image. In other cases, the change in the structure of the pyramid has also created a new type of its use, namely, the pyramid being raised above the cubic dimension at the level of the second floor. For example, the aforementioned ice cellar in Sanssouci Park and the pyramid in Stanway House, Tewkesbury Abbey in England built by Robert Tracy in honour of his father John Tracy, (1750). Here, the pyramid is raised above a cubic structure, in the center of which there is an opening, corners are decorated with stone slabs, but the foot of the pyramid - with urns. A similar example can be found in a drawing of Chatsworth Park made by William Kent in the same country, though in front of the entrance there is a four-column portico and the garden building is named Eclectic Roman ruins [11].

The pyramid is not solely used as a park structure. Its image as a burial place could also be found in a church, as it can be seen in St Augustine's church in Vienna (14th and 18th centuries). It was dedicated to the archduchess Maria Christina who was buried there. The author of the monument was the sculptor Antonio Canova and it was created in the period from 1798 to 1805 . In the upper part a medallion with the profile of archduchess is depicted. The pyramid here is shown as the symbol of eternity - a group of people is imminently moving through its gate.

According to G. R. Carrot, there are three phases in the development of the Egyptian Revival, in Britain, Germany, and elsewhere in Europe: Rococo (pictorial), Classically Romantic and Archeological (according to the publications of Napoleonic historians).

\section{Egyptian style in the parks of Latvia's manors}

In the the second half of the 18th century, the creation of landscape parks began in the manors of Latvia. As it was in Western Europe, the parks'

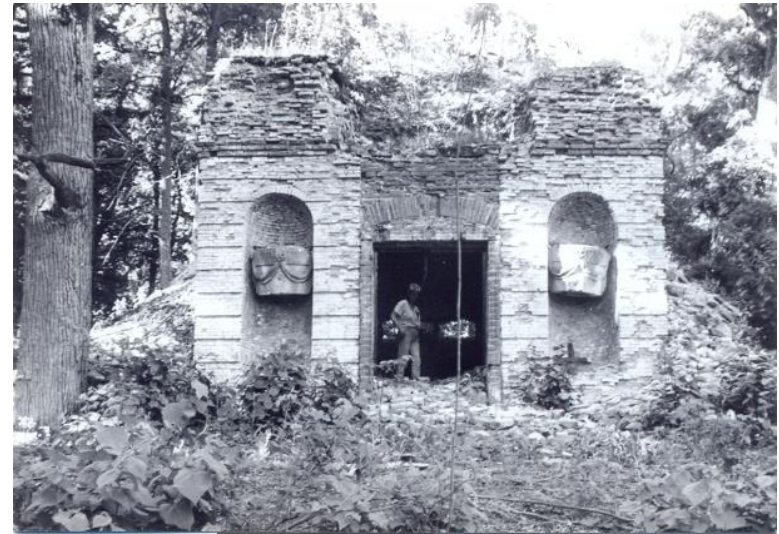

Fig. 6. The chapel in Dunalka Manor, the 1980s

[State Inspection for Heritage Protection of Latvia] architecture - artificial castle ruins, hermits' and meditation houses, monuments like urns and obelisks - was an integral part of them. Chinese pavilions and grottos are also a part of the style of landscape parks of those days. At the beginning of the 19th century, the sentimental small architectural forms which were so popular in the parks as, for example, false tombstones and artificial castle ruins had disappeared. They were replaced by antique forms indicating the increasing influence of Classicism. The pavilions, temples and chapels started to decorate the parks. Regarding the chapels, pyramids should be mentioned as a unique phenomenon of which, the two most famous ones are found in Dunalka (Dubenalken) Manor (early 19th century) and Ropaži (Rodenpois) Manor (late 18th century).

The chapel of von Fircks, the owner of the Dunalka manor, had a real pyramidal shape (slightly split at the top) with a monumental portal and a triangular pediment in front of it. There were niches on both sides of the entrance, where quite big urns were placed. Above the door was an inscriptiontribute in Latin, but the center of the pediment was decorated with the coat of arms of von Fircks family enclosed in a spiral acanthus. Above the inscription there was a semicircular window with muntins finely separating panes of glass, and on both sides there were rectangular niches in which a face of an angel was depicted enclosed in a wreath and sun beams. The portal was made in the style of Classicism, but the interior of the chapel was quite romantic. Like it was in the previously mentioned J. N. L. Durand's project in 1805, the pyramid was transformed into a cylindrical space, in whose thick stone walls in three rows fourteen radial niches were formed in each row for placing coffins.

Imants Lancmanis characterised the impression of the interior in the following way: the spatial conception is eerie and fascinating, since the viewer standing in the middle of the chapel is as if fired upon by the radiation of the numerous niches waiting for their dues. The idea of the dark niches were supposed 


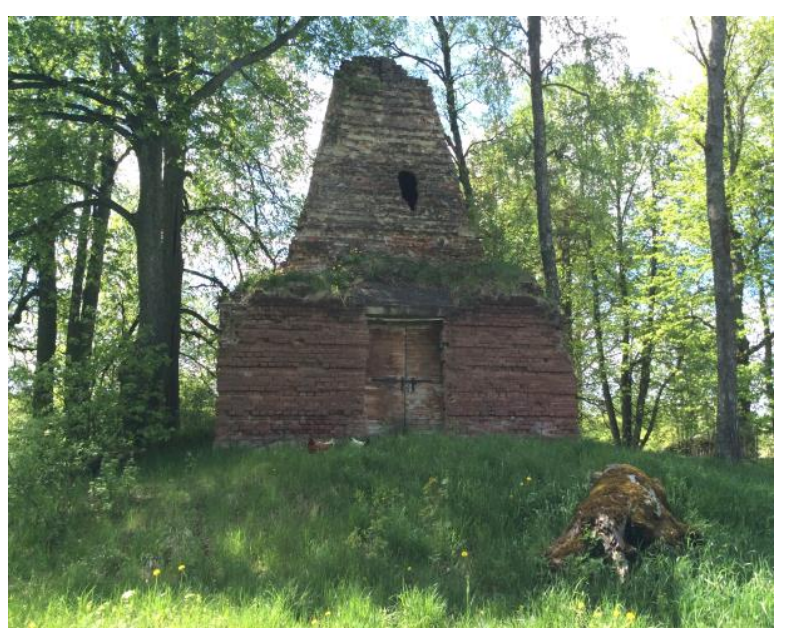

Fig. 7. Ropaži chapel [photo by the author, 2017]

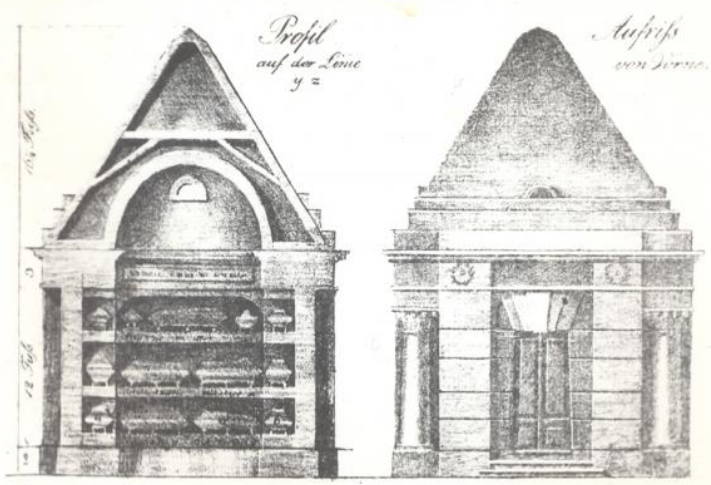

Fig. 8. An example of a chapel

[Rosenplänter J. H. Über Kirchhofe und Beerdigung der Todten, nebst einem

Anhange, den Pernauschen Kirchhof betreffend.

Pernau: Gotthardt Marquardt, 1823]

to make even a heavier impression on the family members - it was a reminder of the end of life not only for the living but also for those generations to be born, that they will inevitably return to this lifetime home [12]. Today the pyramid of Dunalka looks like a heap of miserable ruins. If compared to the chapels found in foreign countries, the closest ones to Dunalka's chapel are those designed by R.Adam and J. Soane as well as Lindenau's family chapel in Machern's manor park near Leipzig (1792, arch. E. V. Glasewald), however the aforementioned project of the architect J. N. L. Durand possibly served as an example for the design of the interior space.

The second type of pyramid - von Wolff's family chapel in Ropaži was lifted above a cube type structure made of red bricks. In its centre there was a door. The façade was decorated with a bas-relief and coats-of-arms, the fragments of which could be still found scattered around the structure. Ropaži chapelpyramid was one of the oldest in Latvia's manor houses. It was built shortly before 1784 by the amateur artist W.D. von Budberg's sketch [13]. In 1791, this structure was featured by
J. C. Brotze [14]. The old building has changed little from its original shape and can still be seen today.

Such type of a pyramid was also built in Dobele cemetery (in the early 19th century) [15]. The outer sides of its cube shaped dimension were covered with tiles and the base of the pointed pyramid was moved aside from the cornice. The mausoleum of J. W. Moller's family in the courtyard of St. Trinity Church in Jelgava (18th century) also had a pyramidal stone roof. However, it had a flat top spire and its shape was gently sloping, making vague associations with the Egyptian culture [16].

A pyramid was also once erected in the landscape park of Varakḷani manor, described by the creator of the park himself - the famous Polish nature scientist and man of letters Count Michael de Borch in his book [17]. He invites the readers to have a stroll in the park with a young man born in the palace, mentioning among many different park structures that under the pyramid painted with hieroglyphs, there was some underground space in the niches of which the urns with ashes of several count's friends were placed [18].

Not far from Liegi manor was a chapel which may also be regarded as one of the so called Ropaži type. Above the square type building was a pyramid that served as the roof for the building. A wide opening with a segmental cover served as an entrance. On both sides of the opening, coats-of-arms were immured in the wall with inscriptions of the people who were buried there.

It is interesting to observe that the Egyptian architecture has even encouraged the publication of sample books in the Baltics, where among other examples, pyramidal buildings are shown. Such is the publication of the priest from Pärnu Johann Heinrich Rosenplänter born in Valmiera [19]. In one of the drawings he depicted a building in the style of Classicism with a pyramid instead of a roof. The interior, as viewed in the section, is covered by a vault. The shape of the doorway opening is also unusual - it is wider at the bottom. The origin of this specific feature is also connected with the Egyptian architecture. It is believed that the author had compiled the data on the existing structures, and the idea of the pyramid as a symbol of eternity, seemed to be topical for him, since his book was written in 1823 .

The manifestations of Egyptian Revival in Latvia are also evidenced by the obelisks that decorated the parks of many large manor as well as smaller manors of suburban Riga. The obelisk culture in Egypt dates back to the Second Dynasty (2890s, 2670s BC). They symbolized the connection between gods and people. The research of obelisks as part of the ancient Egyptian culture was born in the second part of the 19th century, when a special branch of science originated - Egyptology. One of the most interesting obelisks in the manor parks of Latvia is seen in the 


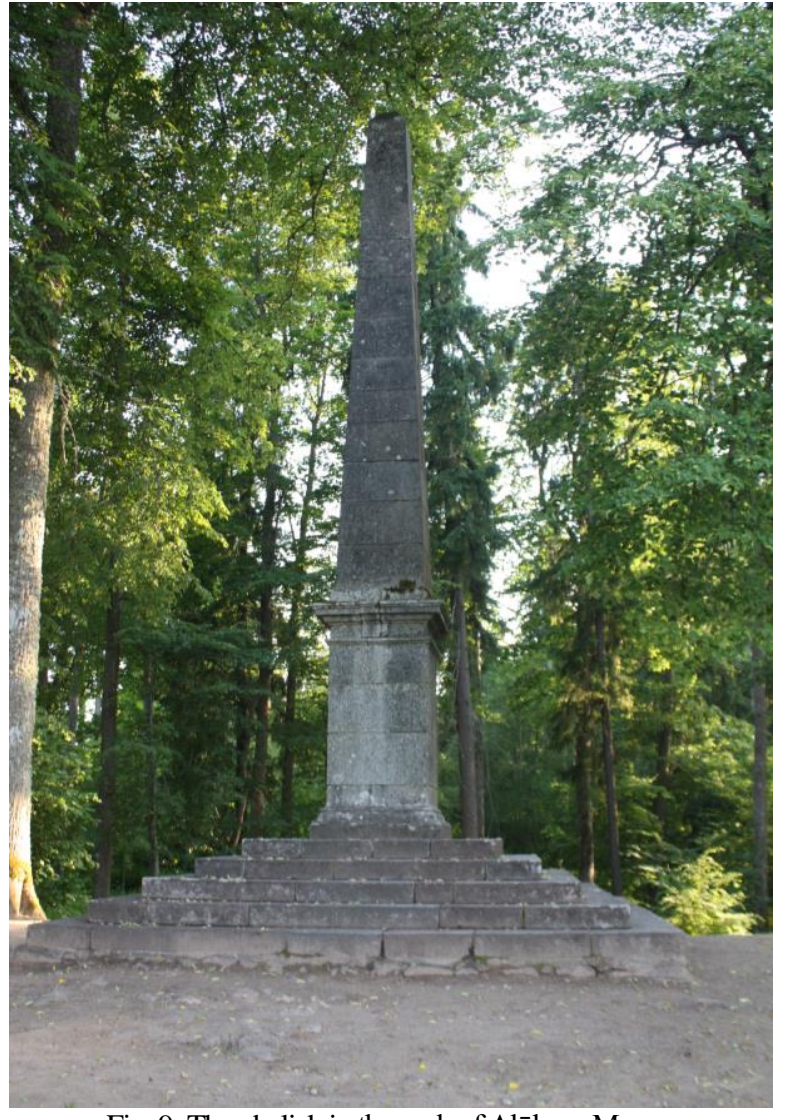

Fig. 9. The obelisk in the park of Alūksne Manor [photo by the author, 2016]

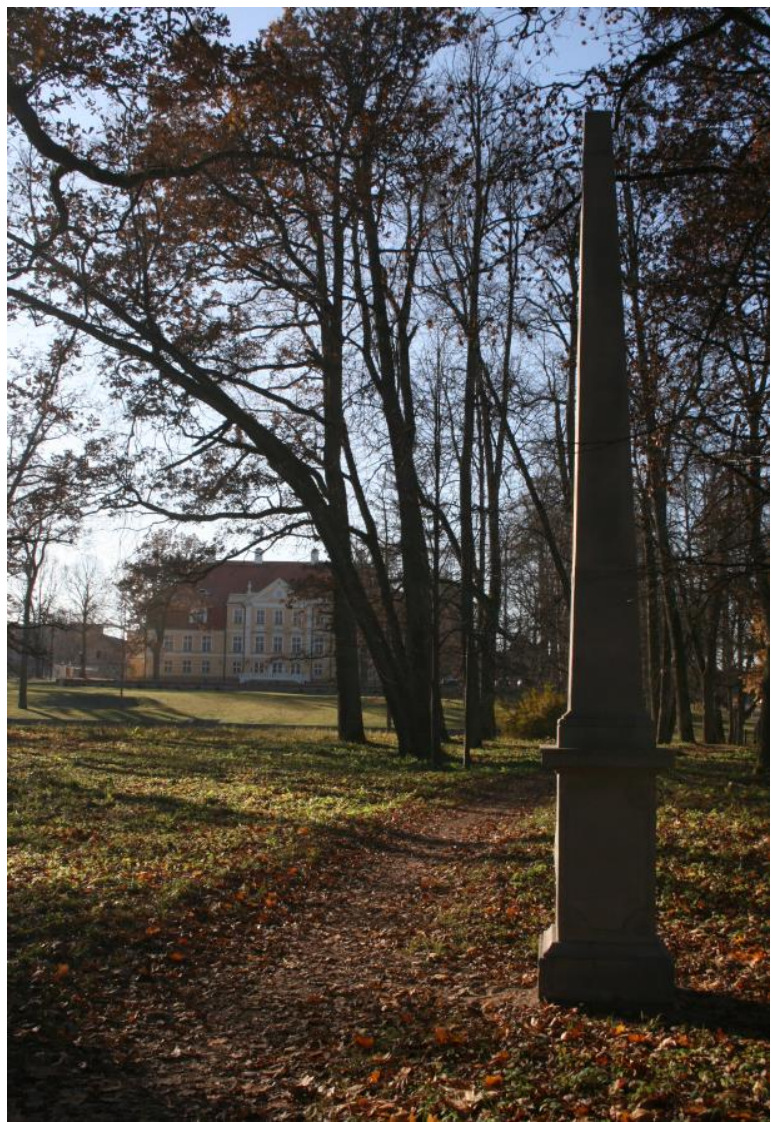

Fig. 10. The obelisk in the park of Mālpils Manor [photo by the author, 2016] park of Napkull half-manor. It is believed to have originated in the early 19th century. The Egyptian hieroglyphs are carved on the sandstone facets of the obelisk, which bear the name of King Ptolemy. Also these types of monuments may have analogies in Western Europe. For example, the monument project Place des Victoires in Paris (1795, architect J. N. Sobre) [20]. This obelisk was intended to be decorated with Egyptian characters. The Napkull halfmanor obelisk, hidden in overgrown bushes is living its last days.

No less interesting was the National Advisor Herman Dahl's monument, which in 1793 was located in Möllershof's small manor in Pārdaugava. The pyramid, which looked almost like an obelisk, as described by J. C. Brotze, was made of wood, but it was treated so that it would look like marble. All the facets of the obelisk were decorated with the silhouette portrait of Dahle himself [21]. The monument was raised on the base, the corners of which were accentuated by urns - very popular elements during the period of Classicism, decorating almost everything - from buildings and furniture to the concepts and ideas expressed in memorial albums. The branches of ivy made of tin girdled the pyramid.

In another drawing of J. C. Brotze - A part of Limbazi cemetry in 1795 one can see a small pyramid of a stone with a white board without an inscription, writes the author of the drawing himself [22]. Also, this pyramid looks almost like an obelisk. It was raised on a low base and its tip was flat topped. Limbaži old cemetery was demolished in the 1960s by creating a park in its place.

An impressive landscape park rich in small architectural forms is located in Alūksne Manor. It reflects the trends of the park art of the second half of the 18th century as well as the innovations of the second half of the 19th century. From the oldest park structures at the end of the 18th century one should mention the granite obelisk built in 1799 to commemorate Otto Hermann von Vietinghoff. The spire of the obelisk was once decorated with a sphere, and the facets - with the bas-relief of the above-mentioned person's profile and inscriptions. One of them read that the monument dedicated to the father was built by his grateful son Christoph Burhard von Vietinghoff.

Also in Mālpils (Lemburg) manor an obelisk made of fine-grain sandstone (fourth quarter of the 18 th century) has been preserved. It was dedicated to the manor's owner Gustav Wilhelm von Taube [22]. The sandstone from which the monument was made is very rare in Latvia, therefore, it is believed to be imported. The main facet of the oval base of the obelisk was decorated with a serpent eating its tail the symbol of infinity. Its enclosed circle contains the inscription: Dem Herrn Gustav Wilchelm Taube, von der Issen 1715. 23. $X-1775$. 23. $X$. The image of the 
serpent has not survived to this day, but it is still visible in the photographs from the 1920s. In the side facet of the base - in a rectangular frame whose corners are folded and contain rosettes, there is an inscription in German that reads: Denkmal, Kindlicher Dankbarkeit Dem Grunder und Erbauer dieser Wohnungen (The monument dedicated to the founder and builder of these houses, built in gratitude by his children). On the other side facet of the base there is another inscription: In allen Geschaeften gleich Thaetig befoelderte Er Das Wohl seiner Mitbrüder und Gründete das Glück seiner Kinder (In all his activities he promoted the benefit of his co-brothers and provided happiness for his children). On the very facet of the obelisk in low basrelief there is a silhouette portrait of von Taube in an oval frame.

In the recreational forest of Bīrini Manor a monument to Ann Helen von Vietinghoff was located. It was depicted by J. V. Krauze in the drawing which was included in the collection of J. C. Brotze [24]. The obelisk was raised on a high base, whose cornice and socle were enriched by profiling. This review of obelisks in the parks of Latvian manors could be continued, thus showing their popularity. Over time obelisks became the monuments for glorification of military fame.

\section{Conclusions}

The Egyptian style in Latvian architecture at the end of the 18th century and early 19 th century was an episodic phenomenon reflecting the wishes and whims of individual aristocrats. However, in other countries, the Egyptian style cannot be quantitatively compared to Neo-Gothic, Neo-Renaissance or Neo-Baroque. It gained greater popularity only in France and in England. The Egyptian Revival movement was iconographic; it did not have (and it could not have had) a local origin and traditions. The monuments and the projects presenting it followed the conceptual lines of romanticism, they were symbolic in nature. It also pertains to the Latvian pyramids, which are vivid examples of the building art of those days. An urgent task would be to preserve the monuments of Dunalka and Ropaži, otherwise only documentary evidence will remain to be placed next to the authentic examples found in other countries. The 18th century pyramids in Europe's parks can be relatively divided into two previously described types. We can be proud that both of them are represented in the architecture of Latvia. They are the chapels in Dunalka and Ropaži. Also the obelisks, which were not a rare phenomenon in our manor parks, played a certain role in promoting the revival of the echo of Egyptian culture. They were most often dedicated to someone's memory.

\section{References}

1. Carrot G.R. The Egyptian Revival: Its Sources, Monuments and Meaning: 1808-1858. Berkeley; Los Angeles; London: University of California Press, 1978. 221 pp. ISBN: 9780520033245

2. Wilton-Ely J. Piranesi: Catalogue. London: Arts Council; Bradford, 1978., p. 39. ISBN: 9780728701762; Hind A. M. Giovanni Battista Piranesi; a critical study, with a list of his published works and detailed catalogues of the prisons and the views of Rome. London: London: The Cotswold Gallery, 1922, plate 21., 22.; Wilton-Ely J. The Mind and Art Giovanni Battista Piranesi. London: Thames \& Hudson, 1978, plate 13., 57. The approach in more detail to Egyptian art by Piranesi was analysed in the publication: Rykwert J. The First Moderns. The Architects of Eighteenth Century. Cambridge, Massachusetts and London: The MIT Press, 1983. 585 pp. ISBN: 9780262680394

3. Neufforge J. F. de. Recueil élémentaire d'architecture. Paris: Auteur, 1758.

4. Erlach J. F.von. Entwurf einer historischen Architektur. Leipzig: 1721., 1725., 1730., 1737., 1742.

5. King D. The complete works of Robert and James Adam. Oxford: Butterworth Architecture, 1991, p. 346. ISBN: 9780750612869

6. Du Prey P., R. de la. John Soane, the making of an Architect. Chicago: University of Chicago Press, 1982, pp. 91, 92. ISBN: 0226172988

7. Essays in the History of Architecture Presented to Rudolf Wittkower. D. Frasern, H. Hibbard (eds.). London: Phaidon, 1967, p. 195, fig. 30. ISBN: 978-0714813004

8. Du Prey P., R. de la, op. cit., p. 92.

9. Description de l'Égypte, ou, Recueil des observations et des recherches qui ont été faites en Égypte pendant l'expédition de l'armée française, publié par les ordres de Sa Majesté l'empereur Napoléon le Grand. France, Commission des sciences et arts d'Egypte. Paris: Imprimerie impériale, 1821-1829.

10. Carrot G. R., op. cit., p. 11., fig. 27; Image republished from: Durand J. N. L. Précis des leçons d'architecture données à l'École polytechnique, Vol. 2. Paris: Chez l'Auteur, 1805.

11. The Fashioning and Functioning of the British Country House (Studies in the History of Art). G. Jackson-Stops et al.(eds.). Washington, D.C.: National Gallery of Art; Hanover; London: University Press of New England, 1989, p. 345. ISBN: 0894681281 of Church of Richmond, USA (1812, architect B. Latrobe) also include this buildings type.

12. Lancmanis I. Iznīcības simboli un romantisms. Māksla, 1995, Vol. 1, p. 70.

13. Lancmanis I. Iznīcības simboli un romantisms. In: Romantisms un neoromantisms Latvijas mākslāa, E. Grosmane (ed.). Rìga: AGB, 1998, p. 54.

14. Brotze J. Ch. Sammlung verschiedner Liefländischer Monumente, Prospecte, Müntzen, Wapen... T. 4., S. 168.

15. Department of Manuscripts and Rare Books of the University of Latvia Academic Library / Latvijas Universitātes Akadēmiskās bibliotēkas Rokrakstu un reto grāmatu nodaḷa, Anša Grīnberga fund., No. 164.

16. Ibidem, No. 145 
17. Jardin sentimental du chateau de Warkland dans le comte de Borch en Russie Blanche. Varsovie: 1795. 29 p.

18. Johansons A. Latvijas kultūras vēsture. 1710 -1800. Stokholma: Daugava, 1975, p. 61.

19. Rosenplänter J. H. Über Kirchhofe und Beerdigung der Todten. - Pernau, 1823.

20. Carrot G. R., op. cit., fig. 30.

21. Broce J. K. Zīmējumi un apraksti, 2. sēj.: Rīgas priekšsilsētas un tuvākāa apkārtne. Rīga: Zinātne, 1996., 2. daḷa, 322. lpp. ISBN: 5-7966-1017-1

22. Broce J. K. Zīmējumi un apraksti, 3. sēj.: Latvijas mazās pilsētas un lauki. Rīga: Zinātne, 2002. 315. lpp. ISBN: 9984698017

23. The Obelisk is included in the List of State Protected Cultural Monuments as a National Art Monument (National Defense No. 4206)

24. Brotze J. Ch. Sammlung verschiedner Liefländischer Monumente, Prospecte, Müntzen, Wapen, etc.: 5 Teil, 1771.

\section{INFORMATION ABOUT AUTHOR:}

In 1979 Jānis Zilgalvis graduated from the Faculty of Architecture of the Riga Technical University. In 1990, he defended his doctoral thesis on the subject of the manor architecture of the second half of the $19^{\text {th }}$ century and the early $20^{\text {th }}$ century. Since then, he is the Head of the Architecture Department of the State Inspection for Cultural Heritage. Since 2012 - a full member of the Latvian Academy of Sciences. Over 180 scientific and popular scientific publications and 18 books (some co-authored). The main lines of the research - the manor architecture and cultural history, sacral architecture, protection of cultural heritage.

Kopsavilkums. Par t. s. ègiptiešu stila izplatību, evolūciju un pieminekḷiem Eiropā veikti vairāki pētījumi, kuros atspoguḷota 18. un 19. gadsimtā neatslābstošā interese par Ëğiptes arhitektūru. 18. gs. modē nāca eksotiski un gleznieciski motīvi un veidojumi, kuru izplatîbu veicināja romantisms, bet uzsāka jau rokoko laika mākslinieki. Tajos galvenokārt skartas formāli estētiska un simboliski ikonogrāfiska rakstura problēmas. Svarīgi bija radīt noteiktu, konkrētai vietai - visbiežāk dārzam vai parkam, vēlamu noskaņu, ko lieliski varēja panākt ar šāda veida eksotiski romantiskām būvēm, kādas bija ḳ̄niešu pagodas, griek̦u tempḷi, gotiskas drupas vai égiptiešu piramīdas un obeliski.

Īpaša loma Egyptian Revival strāvojumā Eiropas arhitektūrā no 18. gs. vidus līdz 19. gs. sākumam bija piramīdām. Tās galvenokārt lietotas piemiņas vietām - apbedījumiem, kapličām, templiem. Piramīdas sastopamas jau mākslinieka Dž. B. Piranezi 1748. gada gravīrās, Ž. F. de Neiforža arhitektūras metu krājumos un J. F. fon Erlaha ilustrētajā arhitektūras vēsturē. Piramīdas forma šajā laikā un arī vēlāk papildināta visdažādākos veidos. Visbiežāk ar klasiskās arhitektūras detaḷām. 18. gs. otrajā pusē arī Latvijas muižās sākās ainavu parku veidošana. Tāpat kā Rietumeiropā to neatņemama sastāvdaḷa bija parku arhitektūra - mākslīgās pilsdrupas, vientuḷnieku un pārdomu namini, pieminekli - urnas, obeliski. 19. gs. sākumā parkos tik iemīḷotie sentimentālie mazo arhitektūras formu darinājumi, kā, piemēram, viltus kapakmeṇi un mākslīgās pilsdrupas bija izzuduši. To vietā nāca antīkās formas, kas liecināja par klasicisma pieaugošo ietekmi. Parkus sāka rotāt paviljoni, tempḷi un kapličas. Pēdējo vidū kā unikāla parādība jāmin piramīdas, no kurām pagaidām pazīstamākās ir divas - Dunalkas (19. gs. sākums) un Ropažu muižās (18. gs. beigas). Dunalkas muižas īpašnieku fon Firksu (von Firks) kapličai bija īstas piramīdas forma, kuras priekšāa pievienots monumentāls portāls ar trīsstūrveida frontonu. Piramīda šodien saglabājusies nožēlojamu drupu izskatā. No minētajiem ārvalstu piemēriem Dunalkas kapličai tuvākie ir R. Adama un Dž. Souna darbi, kā arī Lindenau gimenes kapliča Mahernas muižas parkā pie Leipcigas.

Otra veida piramīda - fon Volfu (von Wolff) dzimtas kapliča Ropažos bija pacelta virs kubveida apjoma. Fasādi rotāja plastiski dekora elementi. Šì piramīda bija viena no vissenākajām Latvijas muižās. Tā celta īsi pirms 1784. gada pēc mākslinieka amatiera V. D. fon Budberga meta. Senā būve no šĩ laika savā apjomā maz mainījusies un aplūkojama vēl šodien. Šāda tipa piramīda atradās arī Dobeles kapsētā (19. gs. s.). Piramidālas formas akmens jumts bija arī J. V. Mollera dzimtas mauzolejam Jelgavas Trīsvienības baznīcas pagalmā (18. gs.). Piramīda atradusies arī Varaklānu muižas ainavu parkā. Interesanti, ka Ėgiptes arhitektūra rosinājusi Baltijā izdot pat paraugu grāmatas, kur cita vidū redzamas piramīdveida būves. Tāds ir mācītāja J. H. Rozenplentera izdevums.

Égiptiešu stils Latvijas 18. gs. beigu un 19. gs. sākuma arhitektūrā bija epizodiska parādība, kas vairāk atspoguḷoja atsevišḳu aristokrātu vēlmes un kaprīzes. Taču arī citās valstīs éǵiptiešu stilu kvantitatīvi nevar salīdzināt ar neogotiku, neorenesansi vai neobaroku. Tas lielāku popularitāti guva tikai Francijā un, Anglijā. Egyptian Revival kustība bija ikonogrāiska, tai nebija (un nevarēja būt) lokālas izcelsmes un tradīcijas. To prezentējošie piemineklị un projekti sekoja romantisma konceptuālajām nostādnēm, tiem bija simbolisks raksturs. Tas attiecas arī uz Latvijas piramīdām, kuras ir spilgti sava laika būvmākslas paraugi. Aktuāls uzdevums būtu Dunalkas un Ropažu pieminekḷu saglābšana, citādi tikai dokumentālas liecības varēsim ierindot blakus citzemju piemēriem. 18. gs. piramīdas Eiropas parkos var nosacīti iedalìt divos jau aprakstītajos tipos. Varam būt lepni, ka abi no tiem ir pārstāvēti arī Latvijas arhitektūrā. Tās ir kapličas Dunalkā un Ropažos. Noteikta loma ēégiptiešu kultūras atskaņu atdzimšanas veicināšanā bija arī obeliskiem, kas mūsu muižu parkos nebija reta parādība. Tie visbiežāk veltīit kādas personas piemiṇai. 